\title{
Pyogenic Granuloma in a Patient on Gefitinib
}

\section{Granuloma Piogénico em Doente a Realizar Gefitinib}

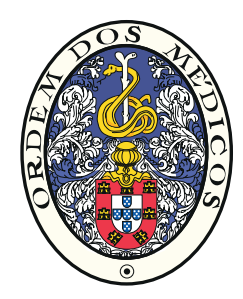

António Fernandes MASSA $\triangle 1$, Ana ANTUNES ${ }^{2}$, Paulo VARELA ${ }^{1}$

Acta Med Port 2016 Jun;29(6):416-416 - http://dx.doi.org/10.20344/amp.6343

Keywords: Granuloma, Pyogenic; Gefitinib.

Palavras-chave: Gefitinib; Granuloma Piogénico.

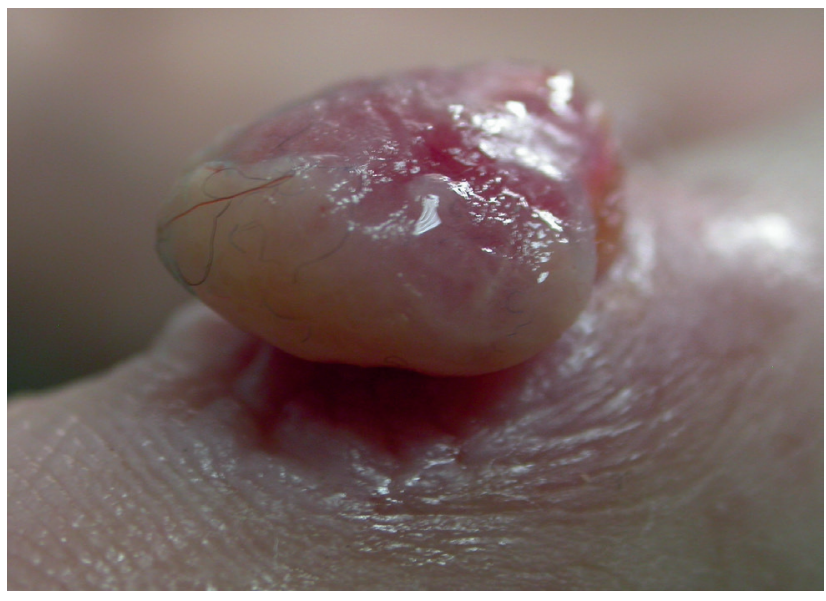

Figure 1 - Erythematous, friable and easily bleeding nodule of 10 $\mathrm{mm}$ on the first phalanx of the left first finger

Gefitinib is an epidermal growth factor receptor (EGFR) tyrosine kinase inhibitor used to treat advanced non small cell lung cancer. The most frequent cutaneous side effect is pilo-sebaceous follicle inflammation. ${ }^{1}$ Pyogenic granuloma $(P G)$ is less common, usually presenting in periungual location associated with paronychia, in a delayed time manner. $^{2}$

We report the case of a 55 -year-old female with stage IIIB pulmonary adenocarcinoma (T3N3M0) EGFR mutated, treated with gefitinib for 16 months with sustained response,

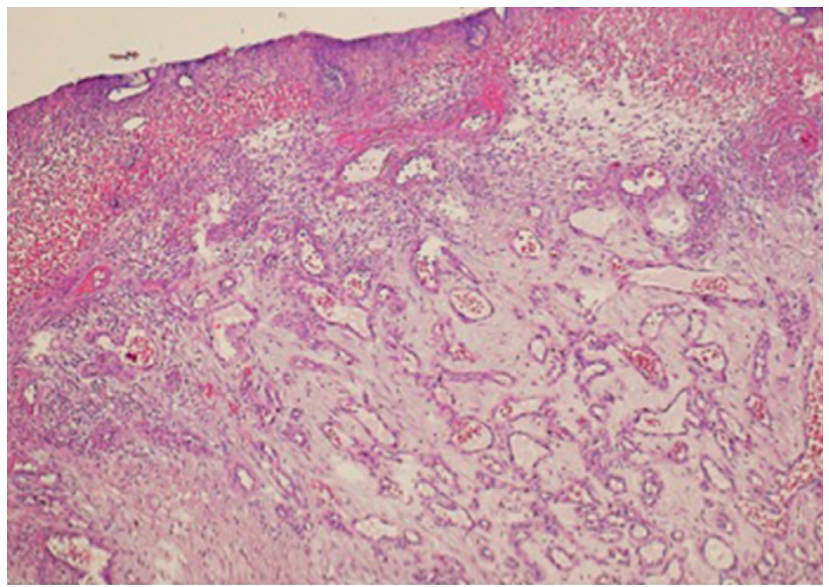

Figure 2 - Lobular haemangioma (HE, $40 \mathrm{x}$ )

with a rapidly growing and bleeding nodule on the finger, with 2 months of evolution, without trauma awareness. At objective examination an erythematous and friable nodule of $10 \mathrm{~mm}$ on the first phalanx of the left first finger was observed (Fig. 1). The diagnosis of PG was made and confirmed after excision, by its histological features (Fig. 2).

Although its aspect was suggestive of PG, an amelanotic melanoma or cutaneous metastasis could not be ruled out without pathologic examination.

\section{REFERENCES}

1. Peuvrel L, Bachmeyer C, Reguiai Z, Bachet JB, André T, Bensadoun RJ et al. Semiology of skin toxicity associated with epidermal growth factor receptor (EGFR) inhibitors Support Care. Cancer. 2012;20:909-21.

2. High WA. Gefitinib: a cause of pyogenic granulomalike lesions of the nail. Arch Dermatol. 2006;142:927-47.

\footnotetext{
1. Dermatology Department. Centro Hospitalar Vila Nova de Gaia/Espinho. Vila Nova de Gaia. Portugal.

2. Pulmonary Oncologic Unit. Centro Hospitalar Vila Nova de Gaia/Espinho. Vila Nova de Gaia. Portugal.

$\triangle$ Autor correspondente: António F. Massa. antoniofmassa@gmail.com

Recebido: 26 de fevereiro de 2015 - Aceite: 29 de setembro de 2015 | Copyright $\odot$ Ordem dos Médicos 2016
} 